ARTICLE HISTORY: Received: September 19, 2021 Accepted: November 12, 2021 Published: November 19, 2021

\title{
DEVELOPING AND REGULATING THE COMMUNIST PARTY OF VIETNAM IN TERMS OF MORALITY UNDER PRESIDENT HO CHI MINH'S POINT OF VIEW
}

\author{
Tran Thi Minh Tuyet \\ PhD in History, Associate Professor, Senior Lecturer, \\ Faculty of Ho Chi Minh's thoughts \\ Academy of Journalism and Communication Hanoi \\ Socialist Republic of Vietnam
}

\begin{abstract}
It can be said that President Ho Chi Minh always upholds the role of revolutionary morality and Party building in terms of ethics. His thoughts have supplemented the theory of Marxism - Leninism on the Party building. In this article, the author analyzes President Ho Chi Minh's ideas in Party building in terms of ethics and proposes some methods for currently developing and straightening the Communist Party of Vietnam.
\end{abstract}

Keywords: Ho Chi Minh, communist movement, Vietnam, Vietnam history.

President Ho Chi Minh is one of the revolutionaries of the communist movement and labor movement interested in matters of morality. His policy of building the Party focuses on not only ideology, politics, and organization like the classic revolutionaries of Marxism-Leninism but also morality. According to him, the Communist Party of Vietnam embodies the intelligence and the "honor and conscience of the nation" [7, p.412]. His statement, "the Party must be moral and civilized," shows that ethical criteria are the leading factor. Morality is considered a vital feature of the Party, which means the Party is no longer a genuine revolutionary one without this character. Therefore, implementing and correctly applying his views is urgent to currently develop and regulate the Communist Party of Vietnam.

1. Building the Party in terms of morality - A great view of Ho Chi Minh.

President Ho Chi Minh's writings indicate that educating and developing morality for all party members is his consistent opinion. When the Party was not established, in work namely "The Revolutionary Road," he wrote about 23 "qualities of a revolutionary," including some crucial features such as "upholding Marxism-Leninism," "no material greed," "walking the talk," and "obeying the orders of organizations." In work named "Modifying the working style," he dedicated a section to write about "Revolutionary ethics" with five fundamental qualities: kindness, fairness, insight, bravery, and frankness. In 1949, while the resistance war against the French was extremely difficult, he wrote the work called "Diligence, economy, honesty, and frankness." He considered them as typical characteristics of revolutionary morality. When the revolution moved into a new phase, building socialism in North Vietnam and struggling against the US puppet regime in South Vietnam, he wrote two articles entitled "Revolutionary Ethics" (in June 1955 and December 1958). In the last year of his life, he left a famous work on morality called "Improving revolutionary morality and abolishing individualism" and another, namely "Will," instructing each Party member to "be truly imbued with revolutionary morality." His views on the importance of morality in Party building are completely consistent with the Vietnamese culture.

Ho Chi Minh explained the role of morality in many aspects to affirm its importance. First of all, he evaluated its importance for the people in general and revolutionaries in particular. He stated that ethics was the core element of revolutionaries because "the revolution transforming the old society into a new one is a glorious career but a challenging task and a complicated, long, and arduous struggle. Strength will fight all problems and maintain a long career. Only when a revolutionary is grounded in morality can he complete the task gloriously" [8, p. 601]. The revolutionary career was full of glory, but there were many obstacles. Because Party was formed secretly and operated under conditions of terror, communists were always on the verge of being killed and imprisoned. People would not dare to participate in revolution activities or became traitors if they lacked morals, loyalty, courage, and self-sacrifice. Thus, ethics helps them be loyal to their chosen ideals and behave appropriately in all circumstances. According to President Ho Chi Minh, revolutionary morality helps people be brave in the face of hardships and failures, as well as remaining honesty and humility if they have reached success. In the revolutionary cause, each person is assigned a different job. Morality will help them avoid jealousy and doubt to become noble. He did not judge people by their titles but their morality because "each person possesses different abilities and tasks, but maintaining revolutionary ethics is vital" [7, p.508].

Ho Chi Minh also emphasized that morality matters were essential to cadres when the revolutionary Party became the governing Party. The power had two sides, and its downside was that it was easy to change human nature. He warned: "In the fights, some people are enthusiastic, loyal, and brave. They have contributed a lot to the revolution. However, they are arrogant, embezzled, wasteful, bureaucratic, and passive when they're in power. They turn into sinners with the revolution" [6, p.361]. He also cautioned about the potential of corruption among senior officials. The more critical their position was, the more likely they were to be corrupted without ethics. He stated: "All officials have power. If they are not industrious, economical, honest, and frank, they easily corrupt and are the problem" [5, p.122]. If 
that "pandemic" occurs, the people will be separated, and the Party's prestige will be damaged. As a result, the revolutionary achievements, which took lots of sacrifice of previous generations of party members and the people, would be destroyed. In addition, the bad habits due to moral degradation will resonate and promote ideological political degradation, leading to betrayal of the chosen goals and ideals, as well as the breakdown of the organization. Therefore, strengthening morality in Party building plays an indispensable role in preventing the risk of the deterioration of a ruling party.

Secondly, President Ho Chi Minh showed the significance of morality in the relationship between talent and morality. He believed that standards were the source of an endowment. "The high enlightenment of communism" is the base of "being capable and specialized," and quality is the foundation of ability. Ethical people always try to learn and strengthen their qualifications and capacity to complete all assigned tasks, so morality will motivate them to reach wisdom. Their natural appeal helps them gather many talented and kind people around them. When they realize their weakness, they will voluntarily support the talented at serving the revolution. Therefore, ethics makes talent flourish and is the origin of talent.

Thirdly, Ho Chi Minh pointed out the importance of morality in doctrine and the revolutionary Party. He argued that morals made philosophy and the revolutionary party appealing. When the revolution had not yet succeeded, the attraction of socialism was not reflected in material and spiritual living standards but the noble qualities of communists fighting and sacrificing for that ideal. Many people joined the revolution due to their love, respect, and trust in communist soldiers. Thanks to that, the revolutionary movement gradually expanded and achieved victory. When the Party becomes the ruling Party, the morality of the cadres and party members will decide the people's trust in the Party. The people can forgive the flaws in the Party's leadership, but they will not tolerate the moral corruption of those who take advantage of their power. Morality is associated with trust. Therefore, revolutionary morality plays a significant role in creating the Party's prestige.

After recognizing the role of morality in many relationships, President Ho Chi Minh concluded: "Success or failure depends on whether cadres are imbued with revolutionary morality or not" [7, p.354]. Developing morals is the premise for enhancing ideology, politics, and organization in the Party building. He said: "If we want to preserve the purity of Marxism-Leninism, we must be incorruptible ourselves" [10, p.468].

The morality that Ho Chi Minh would like to create is a new thing, namely, revolutionary morality. "The old morality and the new one are extremely different. The old one is like a man whose head is on the ground and feet are in the sky, but the new morality is the opposite. In the past, the feudalists mentioned "diligence, economy, honesty, and frankness," but they never did. They forced the Vietnamese to obey to serve their interests. Nowadays, "diligence, economy, honesty, and frankness" are given for officials to implement, making the people follow to benefit themselves and the country," he said [6, p.220]. The subject of new morality is cadres and party members, which indicates his pioneering views on the morals of the communists. Revolutionary ethics is different from the traditional one because it adds a lot of new contents for "loyalty," "filialness," "diligence," "economy," "honesty," and "frankness" and contains completely new standards such as "proletarian international spirit."

Ho Chi Minh identified the criteria of revolutionary ethics on two aspects: the ethics of the Party and the morality of cadres and party members, helping them have a direction to strive.

- Regarding the ethics of the Party:

Becoming the leading force of the class and nation is both a glorious mission of the Party and a great responsibility entrusted by the country. To fulfill its commitment of being the "Driver," the Party needs to converge and crystallize the good values of the national culture and the times. The first thing is about morality. No matter how talented you are, you cannot become a leader without morality. Building the Party in terms of morals creates excellent intrinsic strength, helping it lead the nation. Talking about this issue, he wrote: "Liberating the nation and humanity is a great task. If you don't have ethics, it's hard to finish" [5, pp.292 - 293]. According to Ho Chi Minh, developing the morals of the Party is creating the morals at a "macro" level so that the Party, a unified entity, is responsible for leading the class and the nation. In "Modifying the working style," he stated 12 criteria to determine the status of a true revolutionary Party. The ethics of the Party is expressed in the ideal: "The Party is not an organization that helps cadres more wealthy. Its missions are liberating the nation, making the Fatherland rich and powerful, and helping compatriots happy" [5, p.289]. Therefore, when there was no government, the Party led the people to gain government. When it became the ruling party, it led the people to build a new, prosperous and happy regime. At all times, "the task of our Party is to serve the Fatherland and the people. There is nothing apart from these interests" [7, p.31]. Ho Chi Minh emphasized that the Party was both a leader and a loyal servant of the people. In any situation, the Party must remember that the people's happiness is the reason for its formation and existence. Becoming the ruling Party creates more chances for itself to realize this idea. Dedication is the "core" criterion, which governs other standards to make the Party's nobility.

- Regarding the ethics of each cadre and party member:

The Party is a unified and disciplined organization, so the Party's morality is explicitly expressed through the morality of each party member. Similarly, the righteousness and personality of each party member reflect the morality and nature of the Party. Ethics is the core factor to nurture revolutionaries and party members. Ho Chi Minh said: "If a river has no source, it will dry up. If the tree has no root, the tree will wither. Revolutionaries must be virtuous. 
Otherwise, no matter how talented they are, they will not be able to lead the people" [5, p. 292]. According to Ho Chi Minh, the revolutionary moral standards of party members are evident in the following significant relationships. They must be diligent, economical, honest, frank, and public-spirited in their work. Besides, they need to be loyal and respectful to their country and the people. For humanity, they must have a "pure international spirit" and loyalty. He also drew some teachings for officers as follows: "We shouldn't be arrogant or flatter others. We shouldn't be greedy for other people's property and are not too stingy" [5, p.117]. In addition to the general standards, he established precise ethical criteria for each profession, such as the army, police, physicians, teachers, workers, farmers, intellectuals, and officers.

President Ho Chi Minh gave the principles of revolutionary ethical practice such as: walking the talk, setting examples of morality, developing with preventing issues, and lifelong cultivating ethics to guide Party organizations and their members. However, "walking the talk" is mentioned the most because an action is the most accurate measure of decency and makes people helpful, trustworthy, and respectable.

From the idea of "developing with preventing issues," he agreed that building the Party in terms of ethics was a constant struggle with individualism. We shall eliminate particularism firstly to defeat the external enemy and to be true communists. The battle between revolutionary morality and individualism frequently occurs in each person and organization as the embodiment of good and evil according to the principle of "power creates victory." Therefore, the result will depend on the moral foundation and the will to strive for each person.

"Lifelong cultivating morality" requires a high degree of perseverance from Party members because a good deed does not make a good life. A bad thing quickly ruins a good life if it is severe. Therefore, Ho Chi Minh always encouraged and supported for each communist to persevere and cultivate.

With the outstanding revolutionary morality, he became a communist leader receiving boundless love, as well as the respect of other comrades, the people, and opponents. His attractiveness and persuasion primarily come from morality. His brilliant ideology and ethics are invaluable spiritual assets of the Communist Party and the Vietnamese.

2. Building and regulating the Communist Party of Vietnam in terms of morality - an urgent requirement nowadays.

Doi Moi has marked a critical turning point in Vietnam's growth during the last 35 years. Its accomplishments may be seen in the rising living standards of each family as well as Vietnam's worldwide standing. However, focusing on economic goals, especially the economic growth rate to overcome the risk of economic lag and the downside of the market economy, has caused a problem. Moral education in society and moral reinforcement in the Party have not been paid more attention. The triumph of money, resulting from the primitive market economy and unrestrained authority, has devastated many cadres and party members. This situation has been going on for a long time, so the phrase "degradation of a part of cadres and party members" has been mentioned frequently with growing severity in recent documents of the National Congress of the Communist Party of Vietnam. The $10^{\text {th }}$ National Congress of the Communist Party of Vietnam (2006) commented: "The situation of recession ... of a part of cadres is serious" [1, p.65]. The document of the $11^{\text {th }}$ National Congress of the Communist Party (2011) added the phrase "a huge part of cadres" [2, p.173]. The document of the $12^{\text {th }}$ National Congress of the Communist Party (2016) stated strictly: "The decline in ideology, morality, and lifestyle of a large number of cadres and party members has not been reversed, and even it becomes more complicated in some divisions" [3, p.185]. The document of the $13^{\text {th }}$ National Congress of the Communist Party (2021) wrote: "Some cadres and party members have lost their ideals and will. They are afraid of hardships, and degraded in political thought, morality, lifestyle, "self-evolution", and "self-transformation"" [4, p.92.]. The moral deterioration in the Party is a challenge to the Party building in terms of politics, ideology, and organization. Ethics make political goals humane and help cadres not abuse political power. It also makes their thoughts transparent, loyal, not falling into opportunism. It can be said that it creates unity for an organization because each person knows how to love and respect each other. Ethics and culture are seen as solid foundations in the Party because developing and regulating Party can't achieve good results without them.

Understanding the importance of moral matters in the Party, the document of the $13^{\text {th }}$ National Congress of the Communist Party affirmed a policy of strengthening morality in the Party. Thus, developing revolutionary ethics will apply to not only each individual but also the Party's principles and general way of working. It is both a side that composes the primary contents of Party building and a foundation for Party building in all other aspects.

To achieve that goals, the Communist Party of Vietnam must resolutely implement the following specific solutions:

Firstly, it is necessary to implement Directive No. $05-$ CT/TW of the $12^{\text {th }}$ Politburo on promoting learning and following Ho Chi Minh's thought, morality, and working style, especially in morality. Ho Chi Minh's morality is a noble standard that cadres, party members, and the whole people shall seriously follow. However, inheriting must be true to its nature and become the cultural and personal needs. It's a great idea to combine this mission with a review, evaluation, and summary for each one and organization. Studying and following Ho Chi Minh's moral example should be considered a criterion to evaluate cadres, especially leaders. It is critical to repeat the good examples in this movement to generate a wave of moral revival in the Party and a basis for a moral revival in society. 
Secondly, it is needful to promote the education of personality standards for Vietnamese people in the current period with primary contents such as patriotism, kindness, honesty, solidarity, diligence, and creativity, which are set out by the $11^{\text {th }}$ plenum of the $9^{\text {th }}$ Central Committee.

Thirdly, a fundamental task is to encourage the fight against corruption, bureaucracy, wastefulness, and phenomena contrary to revolutionary ethics. The leaders shall set an example for themselves according to the motto: the higher the position is, the more exemplary they are.

Fourthly, it is crucial to periodically collect the people's opinions on the morality and lifestyle of party members, especially seniors. People with a low credit rating will not be appointed.

Finally, it is compulsory to strengthen education on each cadre and party member's sense of "self-improvement and self-regulation." President Ho Chi Minh wrote: "What is the Party? The Party is each of us. The Party develops if each of us grows up" [9, p.272]. If each party member is a constituent part and represents a part of the morals and nature of the Party, the Party's morality can be judged through the righteousness of each member. Therefore, each person is responsible for fighting not only individualism but also the bad things of his teammates and organizations in the spirit of "standing for the right." Building a clean and strong Party is to make revolutionary ethics for each party member because "without morality, no matter how talented you are, you cannot be a leader" [5, p.292.].

"Revolution shall know how to protect itself." Similarly, each person and revolutionary Party shall control themselves so as not to deteriorate. Focusing on revolutionary ethics becomes a regular and urgent task of the whole Party and each communist.

\section{References:}

1. Communist Party of Vietnam. The document of $10^{\text {th }}$ National Congress. Hanoi: National Political Publishing House, 2006.

2. Communist Party of Vietnam. The document of $11^{\text {th }}$ National Congress. Hanoi: National Political Publishing House, 2011.

3. Communist Party of Vietnam. The document of $12^{\text {th }}$ National Congress. Hanoi: National Political Publishing House, 2016.

4. Communist Party of Vietnam. The document of $13^{\text {th }}$ National Congress. Hanoi: National Political Publishing House, 2021.

5. Ho Chi Minh. Complete Volume, vol.5. Hanoi: National Political Publishing House, 2011.

6. Ho Chi Minh. Complete Volume, vol.7. Hanoi: National Political Publishing House, 2011.

7. Ho Chi Minh. Complete Volume, vol.9. Hanoi: National Political Publishing House, 2011.

8. Ho Chi Minh. Complete Volume, vol.11. Hanoi: National Political Publishing House, 2011.

9. Ho Chi Minh. Complete Volume, vol.13. Hanoi: National Political Publishing House, 2011.

10. Ho Chi Minh. Complete Volume, vol.14. Hanoi: National Political Publishing House, 2011. 